\title{
Rare Complication in The Coronary Angiography Laboratory: Stent Stripping
}

\section{Koroner Anjiografi Laboratuvarında Nadir Karşılaşılan bir Komplikasyon: Stent Sıyrılması}

Hasan Sari ${ }^{1}$, Yakup Alsancak ${ }^{1}$, Selman Soylu², Ahmet Seyfeddin Gurbuz ${ }^{1}$, Mehmet Akif Duzenli ${ }^{1}$

${ }^{1}$ Necmettin Erbakan University, Meram Faculty of Medicine, Department of Cardiology, Konya, Turkey

${ }^{2}$ Necmettin Erbakan University, Meram

Faculty of Medicine, Konya, Turkey

Address correspondence to: Hasan Sari, Necmettin Erbakan University, Meram Faculty of Medicine, Department of Cardiology, Konya, Turkey e-mail: hasansarimd@gmail.com

Geliş Tarihi/Received: 27 May 2021 Kabul Tarihi/Accepted: 2 August 2021

\begin{abstract}
$\ddot{O} z$
Yabancı cisim embolizasyonu, perkütan koroner girişimin nadir bir komplikasyonu olmasına rağmen, işlem sayısının artması, bu sorunun girişimsel kardiyologlar tarafından daha sık karşılaşılmasına neden olmaktadır. Son yapılan vaka çalışmaları, stent sıyırma oranının \% 1 'in altında olduğunu bildirmiştir. Girişimsel kardiyologlar, günlük pratikte önemli sayıda vakayla ilgilenir ve çok çeşitli komplikasyonlarla karşı karşıya kalır. Stentin sıyrılması, acil koroner baypas cerrahisi, koroner tromboz, miyokardiyal enfarktüs, serebrovasküler olay ve ölüm gibi ciddi komplikasyonlara neden olabilir. Bu nedenle, stent sıyırımasının doğru yönetimi, mortalite ve morbidite riskini azaltmak için önemlidir. Bu vaka da sol ana koroner arterde stentinin sıyrılma olgusunu sunuyoruz; sıyrılan stentin kaldırma prosedürünü ve ortaya
\end{abstract}

Anahtar Kelimeler: Stent sıyrılması, koroner anjiografi, girişimsel kardiyolog, embolizasyon

\begin{abstract}
Although foreign body embolization is a rare complication of percutaneous coronary intervention, the increase in the number of procedures results in this problem being more frequently encountered by interventional cardiologists. Contemporary case studies have reported the rate of stent stripping to be below $1 \%$. Interventional cardiologists attend to a considerable number of cases in everyday practice and witness a diverse spectrum of complications. Stent stripping can result in severe complications such as emergency coronary bypass surgery, coronary thrombosis, myocardial infarction, cerebrovascular event and death. Thus, the proper management of stent stripping is important for reducing the risk of mortality and morbidity. In this article, we present a case of left main coronary artery stent stripping; we discuss the removal procedure and the complications that arose.
\end{abstract}

Key words: Stent stripping, coronary angiography, interventional cardiologists, embolization
Cite this article as: Sari H, Alsancak $Y$, Soylu S, Gurbuz AS, Duzenli MA. Rare Complication in The Coronary Angiography Laboratory: Stent Stripping. Selcuk Med J 2021;37(3): 279-282
Disclosure: None of the authors has a financial interest in any of the products, devices, or drugs mentioned in this article. The research was outside organization. All authors have agreed to was not sponsored by an outside organization. All authors have agreed to allow full access to the primary data and to allow the journal to review the data if requested. 


\section{INTRODUCTION}

Although foreign body embolization is a rare complication of percutaneous coronary intervention, the increase in the number of procedures results in this problem being more frequently encountered by interventional cardiologists. Contemporary case studies have reported the rate of stent stripping to be below $1 \%$ (1). In previous times, coronary stents were manually mounted onto balloons. It has been proven that manually mounted stents have greater rates of stripping compared to prepared stents (2). With the development of modern technologies, the complications associated with stent stripping continue to decrease. Stent stripping can result in severe complications such as emergency coronary bypass surgery, coronary thrombosis, myocardial infarction, cerebrovascular event and death. Thus, the proper management of stent stripping is important for reducing the risk of mortality and morbidity. In this article, we present a case of left main coronary artery stent stripping; we discuss the removal procedure and the complications that arose.

\section{CASE}

A 67 year old female patient presented to the cardiology polyclinic with recently intensifying chest pain that increases with effort; the patient had a medical history of hypertension. Although the patient's physical examination did not demonstrate any pathological findings, she was transferred to the coronary angiography laboratory due to unstable angina. Coronary angiography was performed via the right femoral artery. The coronary angiography revealed $80 \%$ proximal stenosis of the LCx (left circumflex artery), 99\% stenosis just before the OM (obtuse marginal) separation and $90 \%$ stenosis in the middle of the LCx. There were non-critical stenoses of the other coronary arteries. The LCx was considered responsible for the patient's complaints. Two floppy guidewires were directed towards the LCx lesion and $\mathrm{OM}$ artery. The lesion was then predilated using a $1.5 \times 15 \mathrm{~mm}$ balloon. Subsequently, we attempted to move a $2.5 \times 15 \mathrm{~mm}$ stent towards the distal end of the lesion. However, the stent could not pass the proximal LCx to reach the lesion. The stent and balloon were then retrieved, but the stent had stripped off the balloon. Non-contrast imaging revealed the stripped stent inside the LMCA (left main coronary artery). The stent was crossed with the existing floppy guidewires (Figure 1). The retrieval of the stent was attempted, however, only the floppy guidewires

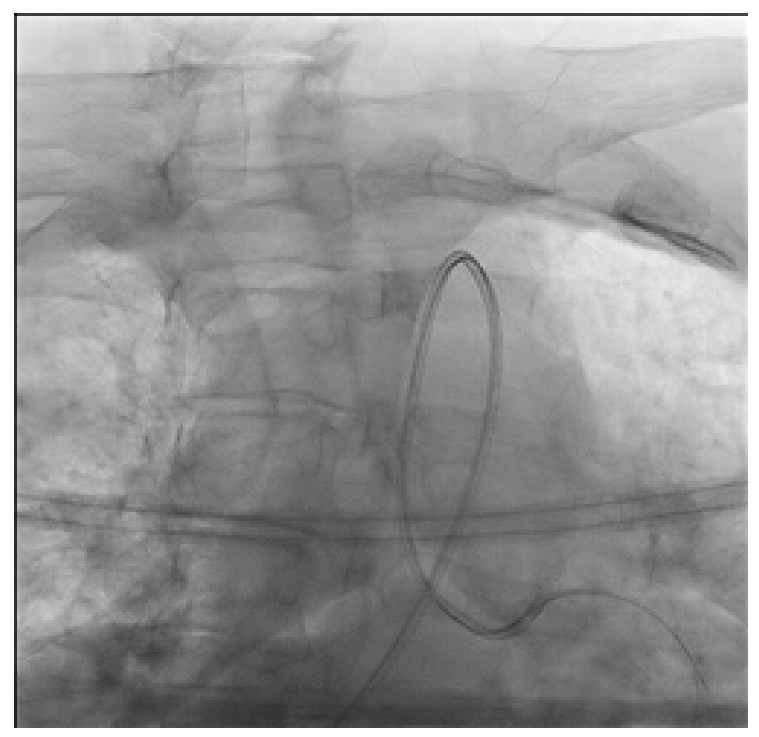

Figure 1. The stent was crossed with the existing floppy guidewires.

had returned. Afterwards, a $1.2 \times 15 \mathrm{~mm}$ balloon was pushed past the distal end of the stent and inflated with a low atm; the stent was held (Figure 2). The stent was grasped with a catheter tip, but the stent and balloon had separated while on the catheter. The stent was then held with another $1.25 \times 15 \mathrm{~mm}$ catheter, it could not be held inside the catheter but was controlled from the wires; within the ostium, the

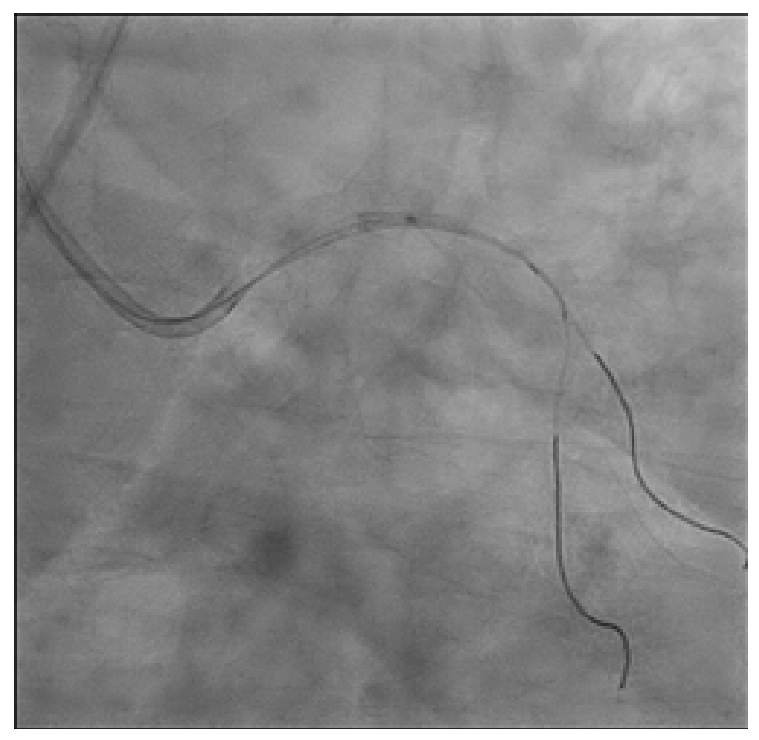

Figure 2. Afterwards, a $1.2 \times 15 \mathrm{~mm}$ balloon was pushed past the distal end of the stent and inflated with a low atm; the stent was held. 
stent and balloon separated and a distal embolization occurred. The location of the stent was investigated; cranial imaging came back clean, distal imaging showed that the stent was located on a medial branch of the deep femoral artery (Figure 3). Due to risk of thrombosis, the preferred method of approach was retrieval using a snare catheter. An $8 \mathrm{~F}$ sheath was placed in the left femoral artery and the opposite side was accessed with an IMA (Internal mammary artery) catheter. It was exchanged a right guiding catheter. The segment distal to the stent was accessed with a hydrophilic wire. A snare catheter was then guided to the same location. The stent was held with the snare catheter, but was later displaced after the stent folded in the catheter opening. The retrieval of the stent was attempted again, but was unsuccessful. A floppy guidewire was then pushed past the stent and a $1.25 \times 10 \mathrm{~mm}$ balloon was used for retrieval. However, the stent could not be retrieved and the procedure was terminated. Control imaging showed minimal extravasation at the stent site. The procedure was finished. The department of cardiovascular surgery was consulted. The patient's complete blood count and clinical status were being monitored. The hemoglobin and hematocrit had seen a $2.8 \mathrm{~g} / \mathrm{dL}$ and $6 \%$ drop, respectively, and a contrast CT (computer tomography) of the iliac and femoral arteries were taken, showing no signs of extravasation. The healthy

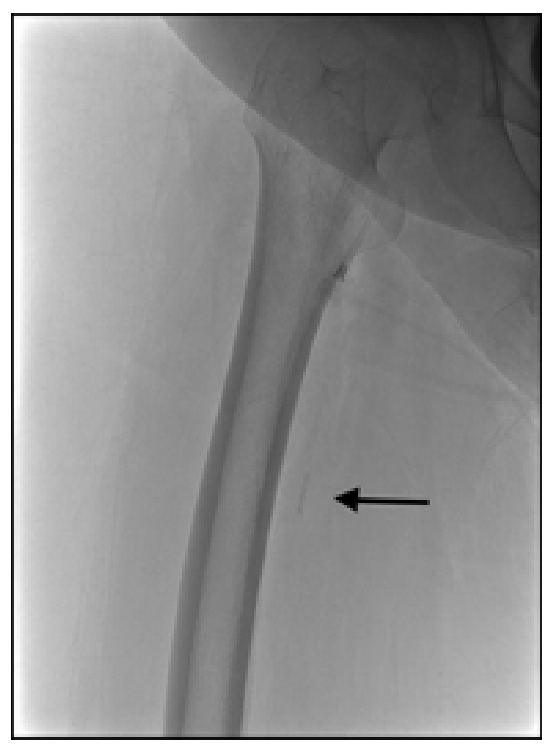

Figure 3. The location of the stent was investigated; cranial imaging came back clean, distal imaging showed that the stent was located on a medial branch of the deep femoral artery. patient was discharged. She returned 2 weeks later for a control physical examination and no pathology was observed.

\section{DISCUSSION}

Interventional cardiologists attend to a considerable number of cases in everyday practice and witness a diverse spectrum of complications. Vascular access complications include bleeding (hematoma, retroperitoneal hemorrhage, pseudoaneurysm), the creation of arterio-venous fistulae, arterial dissections, vessel rupture, infection, embolism, and thrombosis $(3,4)$. In percutaneous coronary intervention, a rare but potentially severe complication of stent application is the stripping of the stent. This may lead to systemic or coronary embolization, which can result in serious morbidity or mortality (5). If the stent gets stripped in the coronary artery, the initial approach should be to evaluate the stent's location and, depending on the situation, plan its retraction or implantation. The stent should be pulled back if possible or implanted onto a proper location within the artery. If the stent is to be implanted, it should be completely adhered to the arterial wall and no malapposition should be permitted (6). During the process of stent retrieval, there are several useful methods such as removal of the stent with a snare, dilating a thin balloon on the distal end of the stent and subsequently latching the stent onto the catheter, and sliding another wire past the stent and performing the twisted guide wires maneuver with the stent wire. Although it is difficult to foresee the stripping of a stent, there are certain risk factors. Being mindful of these risk factors and accordingly taking preventive measure through the use of an assistive catheter, coaxial catheter placement and predilation will reduce the risk of stent stripping (7). In this case, we initially attempted a twisted guide wires maneuver using the wires inside the stent and were unsuccessful. Subsequently, we pushed a balloon through the stent, inflated it with a low atm and carried the stent into the femoral artery; peripheral embolization occurred after. We then attempted to retrieve the stent from the peripheral artery using a snare catheter but failed. Nevertheless, this case illustrates that primary $\mathrm{PCl}$ can be complicated by an embolized stent. This condition might cause neurological events, peripheral arterial ischemia and delayed revascularization, resulting in less favorable outcomes (8). For this, clinicians should consider preventing stent stripping before it can potentially occur; steps of precaution include ensuring that the 
guide catheter is aligned linearly with the coronary ostium and predilation of severe target lesions. Every case of stent stripping is unique with respect to the method of stent retrieval; for this reason, the use of various techniques alone or in combination should be considered. All potential complications should be noted and the necessary equipment must be readily available in the catheter laboratory.

Conflict of interest: Authors declare that there is no conflict of interest between the authors of the article.

Financial conflict of interest: Authors declare that they did not receive any financial support in this study.

Address correspondence to: Hasan Sari, Necmettin Erbakan University, Meram Faculty of Medicine, Department of Cardiology, Konya, Turkey

e-mail: hasansarimd@gmail.com

GSM: 05362265636

\section{REFERENCES}

1. Brilakis ES, Best PJM, Elesber AA, et al. Incidence, retrieval methods, and outcomes of stent loss during percutaneous coronary intervention. Cathet Cardiovasc Interv 2005;65: 333-40.

2. Schatz R, Baim D, Leon $M$, et al. Clinical experience with the Palmaz-Schatz coronary stent. Initial results of a multi-center study. Circulation 1991;83:148-61.
3. Johnson LW, Esente P, Giambartolomei A, et al. Peripheral vascular complications of coronary angioplasty by the femoral and brachial techniques. Cathet Cardiovasc Diagn 1994;31:165-72.

4. Mehmet I, Ömer T, Yüksel D, et al. Gradual treatment of arteriovenous fistula in femoral vessels as a complication of coronary angiography. Braz $J$ Cardiovasc Surg 2018;33(6):631-3.

5. Emmanouil S, Brilakis MD, Patricia JM. et al. Incidence, retrieval methods, and outcomes of stent loss during percutaneous coronary intervention: A large single-center experience. Cardiovasc Interv 2005;66(3):333-40.

6. Eggebrecht $\mathrm{H}$, Haude $\mathrm{M}$, von Birgelen $\mathrm{C}$, et al. Nonsurgical retrieval of embolized coronary stents. Catheter Cardiovasc Interv 2000;51(4):432-40.

7. Değirmenci H, Bakırcı EM. Koroner stent sıyrılmasına yaklaşım. MN Kardiyoloji 2018;25(2):87-92.

8. Mustafa Y, Nesim A, Yalin TY. Successful transcatheter retrieval of the embolized coronary stent during primary percutaneous coronary intervention. J Med Cases 2016;7(10):417-9. 